DOI $10.31651 / 2524-2660-2018-14-3-9$

ORCID 0000-0001-7594-0564

BAIDAK Yurii,

Doctor in Engineering, Professor, Thermodynamics and Renewable Energetics Department, Odesa National Academy of Food Technologies e-mail: yuribaydak@ukr.net

ORCID 0000-0002-9262-6769

\title{
VEREITINA Iryna,
}

PhD in Pedagogy, Associate Professor, Foreign Languages Department, Odesa National Academy of Food Technologies e-mail: kozak_admin@ukr.net

ORCID 0000-0001-8236-7794

\section{POPEL Oksana,}

PhD in Pedagogy, Associate Professor, Foreign Languages Department, Odesa National Academy of Food Technologies e-mail: ksenjapopel2580@gmail.com

УДК $378: 348.1$

\section{VIRTUAL EDUCATIONAL ENVIRONMENT FOR STUDYING PURPOSES}

\begin{abstract}
Introduction. Nowadays the system of future engineers training is entering the new stage of its development and new horizons are opening - connected with formation of teaching pluralism, developing of new teaching ways and methods, which lead to the appearance of new approaches to training process due to the necessity of novel technologies implementation that should support students motivation for lifelong learning and stimulate their creativity. E-learning, $m$ learning, interactive e-books, virtual learning realities - such neologisms integrate to all spheres of education constantly, and engineering training is not an exception.
\end{abstract}

Purpose. The aim of the paper is to specify the main methodological and psychological principles of virtual educational environment creation and implementation.

Results. Essential features of the "virtual learning environment" concept are described and fundamental properties of virtual learning environment which is used in the educational process are given.

Originality. The major pro and contra arguments of these novelties utilization for the educational purposes in the process of training are observed in the paper on the example of virtual gamificated learning environment creation.

Conclusion. Pedagogic system which corresponds to the virtual learning in the artificial environment, should be considered as situational, because the features of its application are determined each time by the specific conditions of training and that virtual educational situation that exists only in this area, at this time, between specific subjects and objects of education. The necessity of the special didactics development for virtual learning environments is obvious. It is necessary to create and implement virtual learning environments for every discipline

Keywords: E-learning; m-learning; interactive e-book; virtual learning environment

Introduction. The learning process is a purposeful activity, during which the problems of education are solved. All functions of education are mediated through information. Proper organization of the educational information transfer and processing creates the conditions for active and successful learning. Personal development is the basis of a general educational process, which in modern pedagogical science is called teaching technology of person formation [1].

The main task of learning as a process of person formation is to create ways and means of information possibilities utilization through its impact on people during the learning process. Personality-oriented education is learning where the personality of the student, his identity, self-worth is put on the first place; subjective experience of each student is first disclosed and then coordinated with education content [2]

If we consider the learning process in terms of the knowledge and skills system formation for the activity in certain situa?ions, it can be argued that virtuality is one of its basic principles. Appeal to the imagination of the student as to the mechanism of generating the virtual world in the traditional form of learning takes place when the teacher begins his story on the topic of the lesson [3].

The process of professional training at any educational technology and form of education should take place in a specific environment, being in which the student acquires knowledge [4]. For modeling professionally-oriented learning situations that are unavailable in the conditions of the institution, such environment can be created artifially. Thus, the virtual learning environment can be defined as temporary existing, created for the process of mental perception artificial environment that can 
be expressed through text, illustrations, graphics, music, movies, laboratory equipment, etc. The process which uses a set of specially organized, computeroriented tools and methods for generation and implementation of virtual environments with the purpose of active interaction with them or inside them is virtual.

Theoretical framework and research methods. The major educational technologies for virtual learning process are action-oriented and learner-focused technologies of formation and implementation of computer informationaleducational environment based on a systematically organized collection of organizationally-pedagogical, psych?logical-didactic, communication and software - technical means.

Virtual learning environment today is one of the forms of information technologies utilization in education [5]. As part of the information technology, virtual learning environment has specific educational opportunities in the university education, namely:

- intensification of the learning process, activation of cognitive activity of students by increasing its motivational component;

- wide opportunities for use of professionally-oriented learning situations for the development of abilities and skills;

- fundamentalization of future specialists training in professional disciplines;

- implementation of individual pace of learning, the use of already learned material on practice, that leads to the reduction of time for training.

- systematic, interactive, progressive nature of the process of acquiring/accumulation knowledge through the integration of theoretical and practical training material into an organic whole and the possibility of a permanent modification [6];

- more thorough preparation of the future experts in professional disciplines through the strengthening of theoretical material on the practice that leads to a reduction of training time;

- student-focused orientation, which leads to the removal of the psychological burden on students, the implementation of individual learning pace, and therefore, better learning.
The peculiarities of virtual learning environment are identified by the balanced interaction of education objects (students and teachers) and facilities (computers and other technical training) [7], the use of the totality of means and methods of formation and implementation of virtual images and means for active interaction with them or within them, integration of traditional (real) and programmed instructions using teaching aids and educational - methodical complexes.

It is difficult to find today even one dicipline in the modern curriculum of any educational establishment - from elemenary/higher school to university - which does not need or use any additional appliances - computers, video/audio records, special devices for laboratory wo$\mathrm{ks}$, etc. in the training process. The main reason of this lies not in the lack of tutors' competency who cannot tell their students about this or that phenomenon during the lecture or lesson. The flows of information are so vigorous that new generation of young people who are growing together with new gadgets, which are getting smarter not every day - every hour of their life, cannot imagine their life without them and rightly consider that these electronic tools should be used in the process of study [8]. The students, especially "digital outliers" also become more independent and want to learn what they want by mens of methods they used to. That's why the appearance of virtual learning envir?nments is a logical consequence of the digital revolution and their implementation to the training process is inevitable.

The aim of the paper is to specify the main methodological and psychological principles of virtual educational environment creation and implementation.

Main part. Virtual learning or learning virtually? The role of virtuality in our life is changing and getting more significant with the development of digital technologies and their implementation to our everyday life. But what does it mean for us today? What is "virtual"? If antique philosophers under the term virtus meant virtue or military valor, 100 years ago scientists considered that this term assumed the existence of hierarchical levels of reality.

Today under virtual is understood objects/conditions that do not really exist, but may occur under certain conditions 
and provide full or partial immersion to them. The full immersion in different cases gives the opportunity to integrate real and virtual worlds, sometimes in the form of games e.g. online virtual games - car racing games, pet games, adventure games, etc.

Virtual games help children to develop their reading, math and critical thinking skills (e.g. www.jumpstart.com), online virtual games (e.g. www.primarygames.com) give children of all ages the opportunity to escape reality and live it up in a virtual reality world. With the number and kind of virtual games available online today, kids are learning about various things through these virtual worlds. From taking up avatars that represent them in the virtual world to carrying out various educational tasks and activities, these games give kids the opportunity to express themselves [9].

If games in virtual reality were initially conceived as entertainment for children (of course, with elements of acquaintance with environment or social life habits and mastering some social skills) and adults (e.g. World of Tanks), virtual (artificial) learning (educational) environments are considered today as multipurpose, interactive, all-inclusive means for education / self-education on the basis of system approach for forming some perfect level of social/professional readiness.

So, in higher and university education virtual means computer-simulated environment which can hold theoretical and practical modules for e-learning, intellectual games for m-learning, interactive e-books or virtual learning environment for scientific experiments that are used in the training process.

How to implement virtuality and all these new forms of training into education is still an issue which is a matter of controversy in the scientific community. We can find in different sources that virtual reality (VR) is a computer-simulated environment of the real world or an imaginary world. But educational system in the modern university doesn't need virtual reality in its global meaning, with avatars in some imaginary worlds - only didactic training systems which can be obtained through interactive e-books or virtual learning environments.

Virtuality in education and science allows merging into the real physical processes and the processes of its simulation, penetrating more deeply into the investigated phenomena, seeing and researching something that is not subject to the direct scientific knowledge. It expands the depth of research, for example permits to see the electrical, magnetic and thermal fields, the medium movement in the dynamics of the process in a limited amount of time to carry out modeling of incompatible factors that can lead to destruction. Especially useful it seems to be in the area of social sciences - foreign languages study (free communication without real company), history (possibility to travel to past and to create vision of future), medicine (presence on real operations), etc.

So, the role of virtuality in education is changing - it dominates and is getting the universal character.

But what principles should be laid down as a basis of virtual learning environments creation to make them not entertainment, but real educational systems of the future?

Virtual learning environments creation fundamentals. Motivation. Time of generations change is coming today. Students of new generation are young people, who know what do they need and want to learn. Almost every citizen has a chance to find everything that he/she needs at this moment in extensive world of information effortlessly. So today it is not enough to tell a student that he/she will learn something about the "CPU" or will study "to recognize details of machine". Tutors should find such arguments and explanations that will become stimuli which direct pupils for creative selfish search of information with its further processing and reinterpretation. It is no secret that students do not want to make efforts to learn and prefer ready-made information products. Therefore, finding new reasons to encourage them in the process of acquiring new theoretical and practical knowledge and skills, i.e. giving them motive for learning is relevant. Motivation is the main factor that determines the effectiveness of any activity. It is proved that the effectiveness of training activities is directly related to the strength of motivation. Some guidelines that everyone should study because it is necessary to study, will be a weak motive for the modern 
student, he doesn't want to be like other people, and the first thing he asks - why study? Only organic combination of internal (individual) and external (social) reasons will promote stable, conscious, cognitive student interest in learning the profession at the highest level, and his future self-actualization. This combination will form an internal motive into the process of understanding the problem / task. It has to involve the student to the activity which will be accepted by him as a significant on the psychological level [10].

Psychological aspect. During the creation and development of virtual learning environments it is significant to know the psychological essence of their influence on the consciousness $[11 ; 12]$. That's why the following methodological principles which should be taken into consideration.

The principle of reflection. All mental phenomena are the subjective reflection of objective reality. This form of reflection is the main condition and prerequisite of evolution development and appearance of consciousness form, formed on the basis of social-historical experience which was worked out by mankind. This experience is embodied in different forms, for example in the form of skills and abilities. Consc?ousness is based on social experience and social practice, thus the human-being can understand objects and phenomena and to see them as carriers of certain characteristics, summarized in the form of concepts about these subjects.

The principle of consciousness and activity integrity. Consciousness does not only originate due to the activity, it mediates the activity and provides its management. The human-being do not only perceive objects, he recognizes in them everything that is important to operate with. Thus, getting acquainted with the subject, acquiring generic information about the object, he/she includes the object into the system of its own activity. So, any object becomes the motive for the further activity and directs it.

The ability of a person to realize his/her actions gives the opportunity not only for making decisions to act one way or another, but to anticipate the results of his activity and to set a conscious goal to produce a conscious choice of the way to achieve this goal, to select the best, in his/her opinion, variant of action from several possible ones.

The principle of the psyche activity. Human psyche is active. It does not obey to the environment, but actively interferes into it and changes it. There are two prerequisites of the psyche activity - social nature of human activities (human and social objectives are socially-oriented) and the existence of consciousness (a person is able to understand his actions, and their possible result, the reality around prior and following his intervention).

The principle of psyche historical evolution experience inclusion. Social and historical experience of humanity is enric?hing and developing; it is changing the nature of the joint activity of people, character of arising links and relationships between them. The society, technology, culture development determines the psyche of the individual. At the same time, human civilization development is not possible without the development of consciousness and activity of its constituent individuals. Not only the ways of human activity in the world and reflection of these methods in the minds are changing, but also the nature and objectives of the needs and motives, which, being the result of the society development, determine the necessity for setting and achieving specific goals for each individual.

So, it is necessary to remember what real psychological processes and states, what specific features of students' activity, what psychological principles and reserves should be the basis for virtual learning environment creation if we want to optimize students' activity on knowledge assimilation and skills development.

Methodological aspect. Orientation of Psychology and Education Sciences at the training, the center of which is the identity of the student as a subject of cognitive and creative activity, at the development of student's personality, at the differentiation of the learning process will contribute to the further development of e-learning system with virtual learning environments as a part of this system.

If we consider the process of learning from the perspective of students mastering a system of knowledge, development of 
abilities and skills to work in professionally oriented situations, it can be argued that virtuality is one of its basic principles. The process of training using any approach of educational technology and form of learning must take place in a particular environment, working in which the student acquires knowledge. In the context of the traditional forms of education, access to the student's subconscious as to the program that can draw a picture (which in his/her imagination will continue to perform the function of the virtual environment) takes place at every practical lesson or lecture. But necessity for active and creative participation of all parties in the learning process as a means of activating the backup capabilities of each individual goes by the wayside.

Virtual Learning Environment is a holistic educational system of computerized (programmable) studentcentered learning, adapted to the needs of the student. At the same time each individual student, depending on his/her knowledge and skills at this particular stage of training, is provided with psychopedagogical tools to clarify learning goals, to form an individual program of educational activity, to select the desired variant or level at which a subject matter is studied. The main purpose of the implementation of the virtual learning environment into the educational process is the formation of environment for independent cognitive activity of students, as well as the development of the creative person of the XXI century. This person possesses mega-cognitive skills and is ready for self-education.

The development of further selfeducational needs. Activity of self-learning takes place when the student reflects (recognizes) the activity, sets the appropriate goals and organizes their achievement.

The development of the students' needs in the further self-education and self-improvement are considered today as an integral component of the total educational process at school and at university. In the nearest future, selfeducational activity should be one of the duties of all members of society, a prerequisite for their active social life.
Under the self-education as a pedagogically oriented learning activities phenomenon is meant the acquisition of knowledge on the initiative of the individual in relation to the subject of employment, the amount and sources of knowledge, establishment of the duration and the time of the occupation, as well as the choice of the form satisfying cognitive needs and interests. It is a virtual learning environment that must not only lay the foundations of the students selfeducation activities, ensuring the implementation of didactic principle of the transition from education to self-education, but also shall establish their readiness for self-education on the basis of the inclusion of an organic self-educational activity of students directly in the learning process. At the same time teaching methods and approaches used during the context development should be largely focused on active and independent cognitive activity of students and forms of training organ?zation, have to ensure the integration of the individual characteristics of students, their interests and abilities.

High School and the University must not only lay the foundations of the students' self-education activity, giving it a mass character, ensuring the realization of didactic principle of transition from education to self-education, but also should establish their readiness for selfeducation.

The concept of readiness for selfeducation includes the following components, which act as internal conditions of self-educational activity: deep and strong comprehensive knowledge as the foundation of independent cognitive activity; effective motives, persistent cognitive interests, awareness of personal significance of constant knowledge updating; development of skills of selfmastering of knowledge and skills by using a variety of sources and in various forms of self-education (reading, listening, watching a video, monitoring, experiment); the formation of mental activity operations (analysis, comparison, allocation of substantial synthesis, establishing causal relationships, abstraction); vision of problems and the choice of ways to solve them; ability to self-organization of cognitive activities (choice of sources of 
knowledge and forms of self-planning and self-control).

It should be noted that all of the components of the concept of "readiness for self-education" are relevant in relation to the concept of "virtual learning environment" as a source of educational information, which incorporated the function of self-education.

Conclusion. Pedagogics, which corresponds to the virtual learning in the artificial environment, should be considered as situational, because the features of its application are determined each time by the specific conditions of training and that virtual educational situation that exists only in this area, at this time, between specific subjects and objects of education. The necessity of the special didactics development for virtual learning environments is obvious.

In the nearest future, virtual learning environments described as spaces where task-oriented creativity, directing problemsolving, interactive communication and fruitful collaboration of participants, visible experimentation, and task-oriented inquiry should be the preferred form of information technologies application in education.

Essential features of the "virtual learning environment" concept include:

1) an interactive form of organization and lack of psychological barrier;

2) a complete system of virtual educational situations;

3) existence only in the artificially created virtual educational space;

4) special didactic tools for formation, implementation and adjustment of acquired knowledge;

5) conditions and means which ensure the flow of the learning process.

Any virtual learning environment which is used in the educational process should have the following fundamental properties:

1) to give the student the role of the object who manage his learning process (the student has to modulate the training system, forming context and activity components);

2) to require from the student selfconscious and active learning activities (in case of not following this requirement, the student cannot go to a higher degree of learning and to change the surface of acquired knowledge).

The virtual learning environment created without complying with the basic didactic principles, becomes a one-off game for kids or adults and will not promote neither to education nor to self-education of students. Organization of educational material in a virtual educational environment should contribute first and foremost a complete assimilation of each student in accordance with his/her individual abilities and individual pace of mastering the material under study and recognition of the specific subject content. The main result of the work in a virtual learning environment conditions should be awareness for independent work and readiness for self-diagnosis.

As far as in developing countries it is not very easy to develop and implement into the curriculum huge common environment for all disciplines of the study course because it is an expensive and complex task, it is necessary to do it stepby-step - beginning from the virtual learning environment for every discipline.

\section{References}

1. Common European Framework of Reference for Languages: Learning, Teaching, Assessment (CEFR) http://www.coe.int/t/dg4/linguistic/Cadre1_en. asp.

2. Baeten, M., Struyven, K., \& Dochy, F. (2009). Student - teachers' approaches to learning in relation to their motivation and their perceived competence. Paper presented at the conference of the International Study Association on Teachers and Teaching, Rovaniemi, Finland.

3. Bloom, B.S., Engelhart, M.D., Furst, E.J., Hill, W.H., Krathwohl, D. (1956). Taxonomy of educational objectives: The classification of educational goals. Handbook I: Cognitive domain. New York: David McKay Company.

4. Nijhuis, J., Segers, M., \& Gijselaers, W. (2008). The extent of variability in learning strategies and students' perceptions of the learning environment. Learning and Instruction. 18. 121-134.

5. Farrell, G. (2001) The Changing Faces of Virtual Education. Retrieved from: http: / / www.col.org/virtualed/index 2.htm

6. Richards, J.C., Rodgers, T.S. (1991). Approaches and Methods in Language Teaching. Cambridge: Cambridge Univ. Press. 171 p.

7. Chamorro-Premuzic, T., \& Furnham, A. (2008). Personality, intelligence and approaches to learning as predictors of academic performance. Personality and Individual Differences. 44. 1596-1603.

8. Chamot, A.U., Barnhardt, S., El-Dinary, P., \& Robbins, J. (1999). The learning strategies handbook. White Plains, NY: Addison-Wesley Longman.

9. Vereitina, I., Baidak, Yu. (2015). Personal Educational Activity of a Student in the Interactive Foreign Language Virtual Environment. Educational Alternatives. 13. 546-552. 
10. Vereitina, I., Baidak, Yu. (2015). Virtual educational environment and activation of students professional and creative potential. Proceedings of the conference: Contemporary innovation technique of the engineering personnel training for the mining and transport industry. Ukraine, Dnepropetrovsk. 285-292.
11. Gattengo, C. (1972). Teaching Foreign Languages in Schools: The Silent Way. 2nd ed. NX-Educational Solutions. $152 \mathrm{p}$.

12. Larsen, Freeman D. (1986). Techniques and Principles in Language Teaching. Oxford: Oxford Univ. Press. $142 \mathrm{p}$.

\section{БАЙДАК Юрій,}

доктор технічних наук, професор, кафедра термодинаміки та відновлюваної енергетики,

Одеська національна академія харчових технологій

e-mail: yuribaydak@ukr.net

BEPEITIHA Iрина,

кандидат педагогічних наук, доцент, кафедра іноземних мов,

Одеська національна академія харчових технологій e-mail:kozak_admin@ukr.net

ПОПЕАЬ Оксана,

кандидат педагогічних наук, доцент, кафедра іноземних мов,

Одеська національна академія харчових технологій e-mail: ksenjapope12580@gmail.com

\section{ВІРТУААЬНЕ ОСВІТНЄ СЕРЕДОВИЩЕ ДАЯ ЦІАЕЙ НАВЧАННЯ}

\begin{abstract}
Анотаиія. Нині система підготовки майбутніх інженерів переходить на новий етап свого розвитку та відкривае нові горизонти - пов'язані з формуванням плюралізму в освіті, розробкою нових методів навчання, чо призводять до появи нових підходів до навчального проиесу та необхідності впровадження нових технологій, які повинні підтримувати мотиваиію студентів до навчання протягом усъого життя та стимулювати їх творчість. Е-навчання, т-навчання, інтерактивні електронні книги, віртуальні навчальні реалї - такі неологізми постійно інтегруються в усі сфери освіти, а інженерне навчання не є винятком.

Метою роботи $\epsilon$ визначення основних методологічних та психологічних засад створення та впровадження віртуального освітнього середовииа.

охарактеризовано сутнісні особливості кониепиії "віртуального навчального середовиша" та надано його фундаментальні властивості
\end{abstract}

у статті розглянуто основні аргументи "за" та "проти" використання віртуального освітнього середовища у проиесі навчання.

Педагогічна система, яка застосовує віртуальне навчальне середовище, повинна розглядатися як ситуативна, оскільки особливості ї̈ застосування визначаються кожного разу за спеиифічними умовами навчання та віртуальною освітньою ситуаиією, яка існує лише в иій області, в ией час, міжк конкретними суб'єктами та об'єктами освіти. Необхідність розробки спеиіальної дидактики для віртуальних навчальних середовиш очевидна. Необхідно створити та запровадити віртуальні навчальні середовища для кожної дисиипліни

Ключові слова: електронне навчання; навчання; інтерактивна електронна книга; віртуальне середовише навчання.

Одержано редакиією 22.06.2018 Прийнято до публікаиї 30.06.2018

DOI 10.31651/2524-2660-2018-14-9-17

ORCID 0000-0001-6263-4744

\section{ВІНТЮК Юрій Володимирович,}

кандидат психологічних наук, доцент кафедри теоретичної та практичної психології, Національний університет "Аьвівська політехніка",

УДК 377.3.015.31 : 159.9-051 e-mail: yurvin@ukr.net

\section{РОЗРОБКА НАВЧААЬНОГО СПЕЦКУРСУ "ПСИХОАОГІЯ КОНКУРЕНТОСПРОМОЖНОÏ ОСОБИСТОСТІ}

У статті розглянуті можливості підвишення конкурентоспроможності майбутніх фахових психологів у проиесі їхнього навчання в ВНЗ. Сформульовані вихідні передумови даного дослідження; зроблений огляд наукових публікаиій за даною темою, в результаті з'ясовані погляди фахівиів на дану проблему і можливості ї̈ вирішення. На основі отриманих даних сформований раиіональний підхід до вирішення вказаної проблеми; з його використанням розроблений спеикурс, призначений для формування конкурентоспроможності майбутніх психологів у проиесі їхнъого навчання в ВНЗ. Наведено інформацію про апробаиію розробленого спецкурсу. Зроблені висновки з проведеного дослідження й накреслені перспективи подальших досліджень у даному напрямку.
Ключові слова: підготовка майбутніх фахових психологів; діяльність у ринкових умовах; ринок праиі; конкурениія; навчальний спецкурс; психологія конкурентоспроможної особистості; оптимізаиія проиесу підготовки фахівиів.

Постановка пробиеми. Необхідність діяльності у сучасних умовах ринкової економіки вимагає зміни підходів до процесу підготовки фахівців різного профілю. Це стосується практично всіх сорер діяльності, зокрема, фахових психологів, які змушені працювати за реамій, коли їхні послуги ще не достатньо затребувані нашим суспільством. У ная- 